正会 蕒

昭和 49 年 4 月 11 日 5 月 9 日 現在

上野 照雄 小笠原長宏 勝田純郎 木田㼨

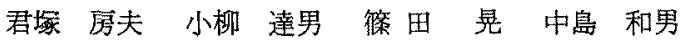
成瀬 済 鳴海 欽一堀江重美 室岡 治義 矢野 信礼横山良国渡辺第二*梅津良逸 *村 田 晃 *和田 長治

*遍加密付 御申込件数 御申込全顧 申込類累計（1974件） 34,201,400 円

\section{入金額累計 $\quad 32,302,378$ 円}

（注）本記念事業資金の御简付について多数の会員の 万々から，寄付金類の基準について搞問合せがごさいま すので，記念事栄資金募集を決定いたしましたさいの募 金小委員会で考えました基準を铺参考供します。

な怙御奇付は，会員の自由意志が建前でございすの で、この基準にこたわらず，広く多数の会員の方々から 御協力をいただければ幸いです。

30 歳以下 2 口, 31 歳 $\sim 40$ 歳 4 口, 41 歳 $\sim 50$ 歳 8 口, 51 歳以上 12 口（1口 2,000 円，分割払いで結櫒です）

\title{
会員名簿訂 正
}

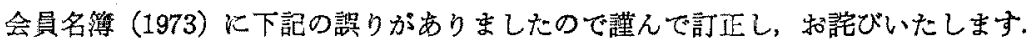

\begin{tabular}{|c|c|c|}
\hline ページ & 誤 & 正 \\
\hline 10 & 清水食品工業(株)社長 鈴木万平 & 社锌 鉿木与平 \\
\hline 68 & 伊任 三郎…徳島市矢三町 & 䰵島市北矢三町 \\
\hline 97 & 大友 俊元…(勤務先) & 東京大学曟学部 \\
\hline 107 & 尾崎 準一...昭 8 & 大 8 \\
\hline 124 & 河津 園子…大谷女子短期大学 & 大阪大谷女子短期大学 \\
\hline 188 & 高 柳 隆…大 14 & 昭 14 \\
\hline 205 & 寺 崎＼cjkstart衛…藤沢薬品工業(株) & 武田薬品工業（株） \\
\hline 233 & 長谷川1武治…7532 豊中市南㮃塚 & $\bar{T} 560$ \\
\hline 292 & 山田 響洋 & 山田 覃洋 \\
\hline$" 1$ & 山田 正一…昭 11 & 大 11 \\
\hline
\end{tabular}

他に会員名簿の愦りがありましたら，和車し出ください。 